\title{
THE
}

\section{The colonial ascidian Didemnum sp. A: Current distribution, basic biology and potential threat to marine communities of the northeast and west coasts of North America}

\author{
S. G. Bullard \\ G. Lambert \\ M. R. Carman \\ J. Byrnes \\ R. B. Whitlatch
}

Follow this and additional works at: https://digitalcommons.uri.edu/gsofacpubs She next page for additional authors

Creative Commons License (c) $($ ) $(9)$

This work is licensed under a Creative Commons Attribution-Noncommercial-No Derivative Works 4.0 License.

\section{Citation/Publisher Attribution}

Bullard, S. G., Lambert, G., Carman, M. R., Byrnes, J., Whitlatch, R. B., Ruiz, G., Miller, R. J.,...Heinonen, K. (2007). The colonial ascidian Didemnum sp. A: Current distribution, basic biology and potential threat to marine communities of the northeast and west coasts of North America. Journal of Experimental Marine Biology and Ecology, 342(1), 99-108. doi: 10.1016/j.jembe.2006.10.020

Available at: https://doi.org/10.1016/j.jembe.2006.10.020

This Article is brought to you for free and open access by the Graduate School of Oceanography at DigitalCommons@URI. It has been accepted for inclusion in Graduate School of Oceanography Faculty Publications by an authorized administrator of DigitalCommons@URI. For more information, please contact digitalcommons-group@uri.edu. 


\section{Authors}

S. G. Bullard, G. Lambert, M. R. Carman, J. Byrnes, R. B. Whitlatch, G. Ruiz, R. J. Miller, L. Harris, P. C. Valentine, Jeremy S. Collie, J. Pederson, D. C. McNaught, A. N. Cohen, R. G. Asch, J. Dijkstra, and K. Heinonen 


\section{The colonial ascidian Didemnum sp. A: current distribution, basic \\ biology and potential threat to marine communities of the northeast and west coasts of North America}

S. G. Bullard ${ }^{1 *}$, G. Lambert ${ }^{2}$, M. R. Carman ${ }^{3}$, J. Byrnes ${ }^{4}$, R. B. Whitlatch ${ }^{5}$, G. Ruiz ${ }^{6}$, R. J. Miller $^{7}$, L. Harris ${ }^{8}$, P. C. Valentine ${ }^{9}$, J. S. Collie ${ }^{10}$, J. Pederson ${ }^{11}$, D. C. McNaught ${ }^{12}$, A. N. Cohen ${ }^{13}$, R. G. Asch ${ }^{10}$, J. Dijkstra ${ }^{8}$, K. Heinonen ${ }^{14}$

${ }^{1}$ University of Hartford, Hillyer College, 200 Bloomfield Avenue, West Hartford, CT 06117, USA bullard@hartford.edu

${ }^{2}$ University of Washington Friday Harbor Labs, Friday Harbor, WA 98250, USA

${ }^{3}$ Geology \& Geophysics, Woods Hole Oceanographic Institution, Woods Hole, MA 02543, USA

${ }^{4}$ Center for Population Biology, University of California, Davis, CA 95616, USA

${ }^{5}$ Department of Marine Sciences, University of Connecticut, Groton, CT 06340, USA

${ }^{6}$ Smithsonian Environmental Research Center, 647 Contees Wharf Road, Edgewater, MD 21037, USA

${ }^{7}$ Biology Department, University of Massachusetts Boston, Boston, MA 02125, USA

${ }^{8}$ Department of Zoology, Spaulding Life Sciences, University of New Hampshire, Durham, NH 03824, USA

${ }^{9}$ Coastal and Marine Geology Program, U.S. Geological Survey, 384 Woods Hole Road, Woods Hole, MA 02543, USA

${ }^{10}$ University of Rhode Island, Graduate School of Oceanography, South Ferry Road, Narragansett, RI 02882, USA

${ }^{11}$ MITSG Center for Coastal Resources, MIT Sea Grant College Program, 292 Main Street, E38-300, Cambridge, MA 02139, USA 
Bullard et al.

${ }^{12}$ Brown University, Department of Ecology and Evolutionary Biology, Providence, RI 02912, USA

${ }^{13}$ San Francisco Estuary Institute, 7770 Pardee Lane, 2nd Floor, Oakland, CA 946211424, USA

${ }^{14}$ National Undersea Research Center, University of Connecticut, Groton, CT 6340, USA

*Author for correspondence: bullard@hartford.edu

Phone: (860) 768-4487

Fax: (860) 405-9153

Running Head: Invasive ascidian Didemnum sp. A on U.S. coasts

Key Words: ascidian; Didemnum; distribution; fouling; Georges Bank; invasive species; nonindigenous; Stellwagen Bank; Tillies Bank; tunicate 
Bullard et al.

\begin{abstract}
Didemnum sp. A is a colonial ascidian with rapidly expanding populations on the east and west coasts of North America. The origin of Didemum sp. A is unknown. Populations were first observed on the northeast coast of the U.S. in the late 1980s and on the west coast during the 1990s. It is currently undergoing a massive population explosion and is now a dominant member of many subtidal communities on both coasts. To determine Didemnum sp. A’s current distribution, we conducted surveys from Maine to Virginia on the east coast and from British Columbia to southern California on the west coast of the U.S. between 1998 and 2005. In nearshore locations Didemnum sp. A currently ranges from Eastport, Maine to Shinnecock Bay, New York on the east coast. On the west coast it has been recorded from Humboldt Bay to Port San Luis in California, several sites in Puget Sound, Washington, including a heavily fouled mussel culture facility, and several sites in southwestern British Columbia on and adjacent to oyster and mussel farms. The species also occurs at deeper subtidal sites (up to $81 \mathrm{~m}$ ) off New England, including Georges, Stellwagen and Tillies Banks. On Georges Bank numerous sites within a $147 \mathrm{~km}^{2}$ area are 50-90\% covered by Didemnum sp. A; large colonies cement the pebble gravel into nearly solid mats that may smother infaunal organisms. These observations suggest that Didemnum sp. A has the potential to alter marine communities and affect economically important activities such as fishing and aquaculture.
\end{abstract}


Bullard et al.

\section{Introduction}

Many ascidians have experienced recent range expansions due to humanmediated transportation, such as the unintentional transport of ascidians on the hulls of recreational and commercial ships (Lambert and Lambert 1998, 2003; Wasson et al. 2001). Ascidians are often strong spatial competitors (Grosberg 1981; Nandakumar et al. 1993; Osman and Whitlatch 1995a; Nandakumar 1996; Castilla et al. 2004) and once they become established in a new location they may persist and become dominant members of their new communities (Lambert and Lambert 2003). In some cases, these rapid population explosions are known to reduce the abundance of previously established benthic species and cause significant changes in benthic community structure (Whitlatch et al. 1995; Bak et al. 1996; Lambert 2001; Castilla et al. 2004).

Didemnum sp. A is an aggressive and rapidly spreading colonial ascidian. Its origin is unknown. Didemnum sp. A was first officially documented on the east coast of the U.S. in 1988 (Table 1), though anecdotal reports suggest that it may have been present as far back as the 1970s. The initially observed populations were isolated and small. During the 1990s, the species began a rapid population expansion and is now a dominant member of many subtidal communities on both coasts of the U.S. (Carman and Roscoe 2003). Indeed, Didemnum sp. A (or several closely related ascidians within the genus Didemnum), seems to be undergoing a rapid world-wide expansion with simultaneous population increases occurring in the United States, Europe (G Breton, personal communication; GL recent unpublished collections; R Sheridan http://staff.umh.ac.be/Sheridan.Richard/inventaire/tun/htm/didemnum.htm), New Zealand 
(Coutts 2002) and possibly Japan (Nishikawa 1990, remarks under description of $D$. pardum and personal communication).

The taxonomy of Didemnum sp. A in the United States remains unclear. Kott (2004) recently described a new species, D. vestum, collected from a marina floating dock in Portsmouth Harbor, Newcastle, New Hampshire that she concludes is an unrecognized native of New England. The description is based on a poorly preserved sample (according to the author and judging from the photos of the few highly eroded spicules still remaining) and lacks larvae. While it appears to resemble our Didemnum sp. A, we cannot comment on the possible conspecificity of Didemnum sp. A to $D$. vestum because of the incomplete description of the latter species. We have not included a description of Didemnum sp. A in this paper because it is morphologically identical to D. vexillum, a recently described species from New Zealand (Kott 2002), in all characters: spicules, larva, tunic and zooid morphology, based not only on the published description but also very careful examination of preserved samples of $D$. vexillum from New Zealand. The reader is directed to this publication for excellent drawings and photos. D. vexillum has a limited distribution in New Zealand (Coutts 2002) and is mostly confined to artificial structures. It is gradually spreading from the initial site of reporting as it has been transported to other harbors on ship hulls.

Didemnum sp. A has a wide but highly disjunct distribution and has only very recently appeared at most sites (see Table 1). The species matches the description of specimens recently identified as D. helgolandicum from Europe (R Sheridan http://staff.umh.ac.be/Sheridan.Richard/inventaire/tun/htm/didemnum.htm) as well as some (but not all) that have been designated as D. lahillei from France (Ates 1998; G 
Breton personal communication). One of us (G Lambert, unpublished observations) has examined the type specimen of $D$. helgolandicum and determined that it is actually $D$. maculosum and thus an invalid species, based in part on the presence of previously undescribed larvae bearing only 2 adhesive papillae, as well as spicule morphology and other characters. This finding agrees with that of Lafargue and Wahl (1987). Populations of Didemnum sp. A that have only recently appeared in northern Europe are thus not D. maculosum because they differ in larval, spicule, zooid and colony morphology from that species. With the help of F. Monniot and T. Turon we have determined that Didemnum sp. A is also not D. lahillei. A careful examination of many taxonomic publications and European specimens has revealed differences in larval and spicule morphology; the name D. lahillei must be restricted to Mediterranean populations with burr-like spicules and larvae with 3 adhesive papillae but only 4 pairs of lateral ampullae (F. Monniot and X. Turon personal communication). Thus the recently reported D. helgolandicum and D. lahillei in northern Europe are not these species but instead closely resemble Didemnum sp. A.

A comparison of mitochondrial DNA is currently underway between Didemnum sp. A from the U.S. east and west coasts, D. vexillum and European Didemnum samples that should help to clarify the taxonomy of the species and its origin. In this paper we refer to the U.S. species as Didemnum sp. A.

Researchers have noticed the rapid expansion of Didemnum sp. A in the United States, but observations have been limited to unpublished reports, press releases, websites and one magazine article (see Carman and Roscoe 2003; http://massbay.mit.edu/exoticspecies/exoticmaps/index.html; 
http://woodshole.er.usgs.gov/project-pages/stellwagen/didemnum/index.htm). The purpose of this publication is to alert marine biologists and aquaculturists to this rapidly spreading and potentially damaging species, to document its known distribution on the east and west coasts of North America (as of November 2005) and to provide initial observations about its ecology.

\section{Materials and methods}

We have compiled verified observations for Didemnum sp. A from Maine to Virginia on the east coast of the United States and from British Columbia to southern California on the west coast. Some of the records were derived from comprehensive surveys for nonindigenous species carried out in these areas, others were from previously established sampling sites. Data used to construct the distribution maps were collected between 1998-2005.

Presence/absence data were collected for Didemnum sp. A at each site. To be considered "present", the species had to either be observed at the site by one of our authors or identified from preserved samples by G. Lambert. Additionally, G. Lambert checked collections from all contributing laboratory groups and verified that all groups were collecting the same species. Anecdotal observations made by fishermen, interested lay-people, or scientists not specifically familiar with the species were not included. To be considered "absent" from a site, one or more of the authors had to have thoroughly searched the site without finding it; however, it is possible that we may have overlooked some small populations. Most of our data were obtained from visual assessments of shallow subtidal communities found on floating docks, pilings and rocks. We examined 
as large an area of each site as possible and collected samples from submerged ropes, tires, boat hulls and the sides and bottoms of docks as far as we could reach with hands and long handled scrapers.

Additional data were obtained from SCUBA surveys of shallow $(<30 \mathrm{~m})$ subtidal sites, photo transects, dredges and ROV surveys of deeper (> $30 \mathrm{~m}$ ) subtidal habitats, and the examination of communities that developed on PVC settlement panels deployed for 3-4 months. Data from settlement panels were included only for sites with Didemnum sp. A settlement because we could not be sure that the species was absent from sites without settlement.

\section{Results and discussion}

Since its first recorded appearance in the 1980s or early 1990s, Didemnum sp. A has become successfully established on both the east and west coasts of North America. It now ranges along approximately $750 \mathrm{~km}$ of coastline on the east coast from Eastport, Maine to Shinnecock, New York and $800 \mathrm{~km}$ on the west coast from Humboldt Bay to Port San Luis, California. Additionally, large populations have recently been found in Puget Sound, Washington and southwest British Columbia (Table 1, Figs. 1-3).

Didemnum sp. A also occurs at deeper subtidal sites (> $30 \mathrm{~m}$ ) on Georges Bank off New England. A complete list of sites, including latitude and longitude data where possible, can be obtained by contacting S. Bullard. The species has apparently not reached its maximum range. All indications suggest that it is continuing to spread rapidly along the coasts of North America and possibly worldwide in temperate climates. 
Very little is known about the ecology of Didemnum sp. A; to the best of our knowledge there are no published studies. The following notes, though largely qualitative, represent a summary of our initial observations of Didemnum sp. A's natural history.

Colonies exhibit a wide range of morphological variation. The pinkish, tan, or pale orange colonies can be long and rope-like (up to about $1 \mathrm{~m}$ in length) or can form undulating, encrusting mats (Fig. 4; see also http://woodshole.er.usgs.gov/projectpages/stellwagen/didemnum/index.htm). They grow on a wide variety of hard substrata and are very common on docks, pilings, subtidal rock outcrops and gravel (pebbles, cobbles and boulders). Growth form may be related to habitat type, current velocities, or space availability, as rope-like forms are common on vertical rock walls and floating surfaces (docks, ropes, boat hulls) in relatively quiet areas, while mat-like colonies are common on rocky seabeds where currents are strong. To date, we have no observations of the species inhabiting exclusively soft-bottom habitats. Similarly, Coutts (2002) noted that colonies of $D$. vexillum that had fallen off the bottom of a barge moored in Marlborough Sounds, New Zealand generally survived if they encountered hard substrata, but eventually died if they landed on muddy or sandy bottoms.

Throughout its current range, Didemnum sp. A is abundant at many nearshore and offshore sites and can grow at depths ranging from $<1 \mathrm{~m}$ to at least $81 \mathrm{~m}$. At many subtidal sites it is a dominant space holder. On the U.S. portion of Georges Bank Didemnum sp. A covers 50-90\% of available space at numerous sites over a $147 \mathrm{~km}^{2}$ area to a depth of 45 to $60 \mathrm{~m}$ (estimated from extensive USGS video and photographic surveys conducted in November 2004 and September 2005); Didemnum sp. A also occurs 
on the Canadian portion of Georges Bank. Similar large populations (> 50\% cover) have been observed by SCUBA on cobble bottoms in eastern Long Island Sound (35 m), rocky bottoms off the Damariscotta River, Maine (10-15 m), rock walls in Agamemnon Channel and Okeover Inlet, British Columbia (5-15 m) and on many marina floats and pilings on the east and west coasts of the U.S. (Table 1). In British Columbia all natural subtidal sites are adjacent to oyster or mussel culture facilities known to be heavily fouled with Didemnum sp. A. Sparse colonization has been observed on Tillies and Stellwagen Banks. Given the occurrence of Didemnum sp. A at several deep-water sites (> $30 \mathrm{~m})$, it is possible that it may be abundant at other offshore locations. However, deep-water habitats are rarely visited and this hypothesis needs to be further explored.

Didemnum sp. A can also grow in the lower intertidal zone. In a shallow tide pool at Sandwich, Massachusetts, colonies encrusted rocks, overgrew other fouling organisms and were able to survive exposure to air during spring tides. Similarly, the upper edges of colonies have been observed out of water at low tide on Jedediah Island, British Columbia (S. Geerlofs personal communication). Colonies at the Massachusetts site persisted throughout the summer and fall, but declined during the winter and were reduced to small basal patches by April and May 2004 (P. Valentine and M. Carman, unpublished data); it is likely that low tide exposure during the winter made colonies vulnerable to low temperatures or ice cover. However, many colonial ascidians overwinter in this fashion (Satoh 1994), and regrowth of Didemnum sp. A was rapid beginning in June 2004.

Like all colonial ascidians, Didemnum sp. A reproduces sexually and broods its larvae. On the east coast, newly settled juveniles have been found at Groton, Connecticut 
from July to November with peak settlement occurring from late August to early September (R. Whitlatch and S. Bullard, unpublished data). Colonies filled with larvae were collected from Georges Bank in November 2003. On the west coast, newly settled juveniles have been found at Bodega Bay, California from July to August (M. Nydam, unpublished data) and colonies containing many mature larvae were collected in May 2003 at Sausalito, California (G. Lambert, unpublished data). In the Pacific Northwest, colonies containing mature larvae were collected in Puget Sound in November 2004 and in southwest British Columbia in December 2004.

In addition to forming new colonies through larval settlement, Didemnum sp. A can also form new colonies asexually by fragmentation. In its rope-like growth form, long flaccid lobes extend from the central portion of attached colonies that easily break off. At subtidal sites in Maine divers have observed lobes break off, become lodged on the surrounding substrata and over the course of several months reattach and thrive in their new locations (L. Harris, unpublished data). Workers at British Columbian oyster farms have reported that numerous large colony pieces slough off the oyster strings when they are pulled out of water. These large fragments, plus others pulled off the oysters and mussels and thrown back into the water, likely contributed to the establishment of Didemnum sp. A on nearby natural subtidal surfaces. Coutts (2002) also noted that in New Zealand some $D$. vexillum colony pieces that fell off the bottom of a barge were able to colonize hard substrata. Fragmentation is common in colonial ascidians (Stoner 1989; Worcester 1994; Edlund and Koehl 1998) and may provide Didemnum sp. A with considerable dispersal potential and two significant ecological advantages. First, reattached lobe fragments might be less susceptible to competition or predation than 
small newly settled larvae (see Osman and Whitlatch 1995b; Marshall and Keough 2003). Second, brooded larvae contained in lobe fragments could be released before or after reattachment and further increase Didemnum sp. A’s dispersal capability. Indeed, Didemnum sp. A may be so widespread on the Georges Bank because it is constantly being disturbed and fragmented by scallop dredging operations, with the colony fragments floating away and reattaching.

To assess the ability for asexually produced Didemnum sp. A fragments to reattach to the substratum, during summer 2004 containers with fragments were placed in the Sandwich, MA tidepool and submerged at a depth ranging from $0.6 \mathrm{~m}$ (low tide) to about 3-4 m (high tide). Fragments were never exposed to air during the tidal cycle. The fragments reattached and grew vigorously. This site is susceptible to storm waves, and during fall 2004 the containers filled with sand. By that time, however, the colonies had grown onto the walls and mesh coverings of the containers. The parts of the colonies that were covered by sand died, but the rest continued to grow and even extended onto the gravelly sand surrounding the containers (P. Valentine and M. Carman, unpublished data). Thus, Didemnum sp. A colonies can apparently withstand some sediment movement as long as they are not buried.

The rapid emergence and successful establishment of Didemnum sp. A in diverse epibenthic communities testifies to its strong competitive ability. It commonly overgrows other ascidian species (both colonial and solitary) as well as sponges, macroalgae, hydroids, anemones, bryozoans, scallops, mussels, tubiculous polychaetes and crustaceans that have completed their terminal molt. On cobble bottoms in Long Island Sound, the only epifaunal species that Didemnum sp. A did not appear to overgrow 
were the northern star coral, Astrangia poculata, and the cerianthid anemone, Ceriantheopsis americana. Didemnum sp. A may be of particular concern for shellfish, and thus the aquaculture industry, as colonies can completely overgrow the siphons of epifaunal and infaunal bivalves and lead to their death. Further, at sites where Didemnum sp. A blankets large areas of the seafloor, its mat-like morphology may smother infauna, reduce the food supply for bottom feeders, inhibit settlement of other organisms, reduce the spatial complexity of benthic habitats and indirectly increase the risk of predation for shelter-seeking fishes (e.g., Auster and Langton 1999).

Didemnum sp. A’s temperature tolerances remain unclear. The current distribution suggests that it is a temperate species. In New England, Didemnum sp. A can live subtidally in water temperatures as low as $-2{ }^{\circ} \mathrm{C}$. It also grows well at water temperatures in excess of $24^{\circ} \mathrm{C}$, as exemplified by the summer survival of intertidal colonies. On the west coast, the species is currently not found south of Point Conception, California, a prominent geological feature associated with a well-defined boundary between cool northern and warm southern waters. It is now abundant in parts of Puget Sound, Washington and southwest British Columbia, where year-round water temperatures usually range from $6-18^{\circ} \mathrm{C}$.

Little is known about possible predation on Didemnum sp. A. A few subtidal photos taken in British Columbia (http://woodshole.er.usgs.gov/projectpages/stellwagen/didemnum/index.htm) show several large seastar species apparently feeding on it. Littorine snails fed on decaying colonies in the Sandwich tidepool (P. Valentine and M. Carman unpublished data). Predation is probably limited, however, due to its probable mechanisms of chemical defense (see below). 
Although our understanding of Didemnum sp. A's ecology is still limited, ecological information is available for other Didemnum species and other members of the family Didemnidae. As a group, didemnids possess several ecological traits that may make them effective invaders. They are often strong spatial competitors and rapid colonizers. In Japan, Didemnum moseleyi is the strongest overgrowth competitor among 36 species of fouling organisms (Nandakumar 1995). In the Red Sea, two species of Didemnum commonly foul artificial reefs and quickly colonize newly exposed substrata (Oren and Benayahu 1998). In the Caribbean, Trididemnum solidum tripled its biomass in nearshore waters off the island of Curaçao during the 1990's, possibly due to large increases in bacterial content of the water (Bak et al. 1996). Chemical defenses have been reported in adults or larvae of many Didemnum species (Vervoort et al. 1998; Pisut and Pawlik 2002; see also Jimenez et al. 2003) as well as other members of the family Didemnidae (Lindquist et al. 1992; Joullie et al. 2003; Michibata et al. 2003). Some of the chemical compounds isolated from didemnids are particularly deterrent. For example, the chemical isolate “didemnimide D” from the Caribbean species Didemnum conchyliatum is one of the more potent anti-predator compounds described and deters feeding by fishes at minute concentrations (Vervoort et al. 1998). Finally, most didemnids have very low surface pH. Pisut and Pawlik (2002) found that Didemnum candidum and D. vanderhorsti both had a surface $\mathrm{pH}$ of less than 3.0, a level of acidity that deterred feeding by generalist fish predators. Didemnum sp. A appears to possess at least some of these traits. Its toxicity and palatability remain untested, but litmus paper tests and hand-held $\mathrm{pH}$ meters indicate that it possesses a highly acidic tunic $(\mathrm{pH}=2$ to 3 ; S. Bullard, M. Carman and P. Valentine unpublished data). 
We predict that Didemnum sp. A has the potential to cause great ecological and economic damage on both coasts of North America. The species continues to expand its range and could eventually colonize large expanses of hard substrata habitats in temperate waters. On the east coast of North America this would include all of New England as well as eastern Canada. On the west coast this would include all areas north of Point Conception, California. It is currently not known whether it can survive south of Point Conception. Food availability may usually limit its occurrence to relatively shallow waters, but at sites where the water column is well mixed (such as Georges Bank) the species will likely continue to flourish at greater depths. Where it blankets the seafloor, Didemnum sp. A may significantly affect fisheries because it can smother bivalves, reduce the structural complexity (i.e., refuge value) of the seafloor, and likely kills infaunal organisms that provide food for fishes and other bottom feeders.

More information is needed about Didemnum sp. A's physical tolerances, life history characteristics and ecological interactions (including its potential predators and competitive ability relative to other species) to assess the specific impacts it may have on marine communities and to develop methods to control or eradicate it. We particularly note that asexual fragmentation could greatly increase its dispersal potential. Initial observations indicate that fragments of adult colonies likely have higher survivorship, and thus greater transport potential, than short-lived, non-feeding larvae. Aquaculture facilities should sanitize all stock and gear before transport to new grow-out areas. The transport of fragments in ballast water might also contribute to the species' highly disjunct distribution, and may assist its spread in the future. 


\section{Acknowledgements}

Funding for this project was provided by EPA (STAR) grant GZ1910464 to R.B.

Whitlatch, NSF-DGE 0114432 to J. Byrnes, NSF-OCE 0117839 to R. Etter and R.J. Miller, MIT Sea Grant NA86RG0074 and USEPA Grant GX83055701-0 to J. Pederson. RI Sea Grant NA07R90363 to J.S. Collie. Funding for A.N. Cohen and G. Lambert was provided by Mass. Sea Grant, U.S. EPA, Smithsonian Envl. Research Center Invasions Lab, Natl. Geographic Soc., San Francisco Bay-Delta Science Consortium_and CALFED Science Program, Calif. Coastal Conservancy and the Rose Foundation. Additional funding and support was provided by the Stellwagen Bank National Marine Sanctuary. We thank P.J. Auster, G. Breton, M.M. Carman, Z.C. Carman, E.I. Collins, A.D.M. Coutts, J. Hamilton, G. King, S. Koch, A. Lamb, J. Lindholm, A. McCarthy, F. Monniot, M. Nydam, R.W. Osman, X. Turon and J. Witman for help with this project. The views expressed herein are those of the authors and do not reflect the views of NOAA or any of its sub-agencies. 
Bullard et al.

\section{References}

Ates, R., 1998. De druipzakpijp, Didemnum lahillei Hartmeyer, 1909 in Zeeland [The sea squirt Didemnum lahillei Hartmeyer, 1909 in Zeeland.]. Het. Zeepaard 58, 101-110.

Auster, P.J., Langton, R.W., 1999. The effects of fishing on fish habitat. In: Benaka, L. (Ed.), Fish habitat: essential fish habitat and rehabilitation. American Fisheries Society, Bethesda, MD, pp. 150-187.

Bak, R.P.M., Lambrechts, D.Y.M., Joenje, M., Nieuwland, G., VanVeghel, M.L.J., 1996. Long-term changes on coral reefs in booming populations of a competitive colonial ascidian. Mar. Ecol. Prog. Ser. 133, 303-306.

Carman, M.R., Roscoe, L.S., 2003. The didemnid mystery. Massachusetts Wildlife 53, 27.

Castilla, J.C., Guiñez, R., Caro, A.U., Ortiz, V., 2004. Invasion of a rocky intertidal shore by the tunicate Pyura praeputialis in the Bay of Antofagasta, Chile. Proc. Natl. Acad. Sci. USA 101, 8517-8524.

Castilla, J.C., Lagos, N.A., Cerda, M., 2004. Marine ecosystem engineering by the alien ascidian Pyura praeputialis on a mid-intertidal rocky shore. Mar. Ecol. Prog. Ser. 268, 119-130.

Coutts, A.D.M., 2002. A biosecurity investigation of a barge in the Marlborough Sounds. Cawthron Institute, Nelson, New Zealand, Report 744, 59 pp.

Edlund, A.F., Koehl, M.A., 1998. Adhesion and reattachment of compound ascidians to various substrata: Weak glue can prevent tissue damage. J. Exp. Biol. 201, 23972402. 
Grosberg, R.K., 1981. Competitive ability influences habitat choice in marine invertebrates. Nature 290, 700-702.

Jimenez, P.C., Fortier, S.C., Lotufo, T.M.C., Pessoa, C., Moraes, M.E.A., de Moraes, M.O., Costa-Lotufo, L.V., 2003. Biological activity in extracts of ascidians (Tunicata, Ascidiacea) from the northeastern Brazilian coast. J. Exp. Mar. Biol. Ecol. 287, 93-101.

Joullie, M.M., Leonard, M.S., Portonovo, P., Liang, B., Ding, X., La Clair, J.J., 2003. Chemical defense in ascidians of the Didemnidae family. Bioconj. Chemi. 14, 30-37. Kott, P., 2002. A complex didemnid ascidian from Whangamata, New Zealand. J. Mar. Biol. Ass. U. K. 82, 625-628.

Kott, P., 2004. A new species of Didemnum (Ascidiacea, Tunicata) from the Atlantic coast of North America. Zootaxa 732, 1-10.

Lafargue, F., Wahl, M., 1987. The didemnid ascidian fauna of France. Ann. Inst. Oceanogr., Paris 63, 1-46.

Lambert, G., 2001. A global overview of ascidian introductions and their possible impact on endemic fauna. In: Sawada, H., Yokosawa, H., Lambert, C.C. (Eds.), The biology of ascidians. Springer-Verlag, Tokyo, pp. 249-257.

Lambert, C.C., Lambert, G., 1998. Non-indigenous ascidians in southern California harbors and marinas. Mar. Biol. 130, 675-688.

Lambert, C.C., Lambert, G., 2003. Persistence and differential distribution of nonindigenous ascidians in harbors of the Southern California Bight. Mar. Ecol. Prog. Ser. 259, 145-161. 
Lindquist, N., Hay, M.E., Fenical, W., 1992. Defense of ascidians and their conspicuous larvae: Adult vs. larval chemical defenses. Ecol. Monogr. 62, 547-568.

Marshall, D.J., Keough, M.J., 2003. Effects of settler size and density on early postsettlement survival of Ciona intestinalis in the field. Mar. Ecol. Prog. Ser. 259, 139144.

Michibata, H., Yamaguchi, N., Uyama, T., Ueki, T., 2003. Molecular biological approaches to the accumulation and reduction of vanadium by ascidians. Coord. Chem. Rev. 237, 41-51.

Nandakumar, K., 1995. Competitive interactions among sessile organisms in Tomioka Bay, south Japan - importance of light conditions on the panel surface. Mar. Biol. $121,713-719$.

Nandakumar, K., 1996. Importance of timing of panel exposure on the competitive outcome and succession of sessile organisms. Mar. Ecol. Prog. Ser. 131, 191-203.

Nandakumar, K., Tanaka, M., Kikuchi, T., 1993. Interspecific competition among fouling organisms in Tomioka Bay, Japan. Mar. Ecol. Prog. Ser. 94, 43-50.

Nishikawa, T., 1990. The ascidians of the Japan Sea. I. Publ. Seto Mar. Biol. Lab. 34, 73148.

Oren, U., Benayahu, Y., 1998. Didemnid ascidians: rapid colonizers of artificial reefs in Eilat (Red Sea). Bull. Mar. Sci. 63, 199-206.

Osman, R.W., Whitlatch, R.B., 1995a. Influence of resident adults on larval settlement: a comparison to settlement. J. Exp. Mar. Biol. Ecol. 190, 169-198. 
Osman, R.W., Whitlatch, R.B., 1995b. Predation on early ontogenetic life stages and its effect on recruitment into a marine epifaunal community. Mar. Ecol. Prog. Ser. 117, 111-126.

Pisut, D.P., Pawlik, J.R., 2002. Anti-predatory chemical defenses of ascidians: secondary metabolites or inorganic acids? J. Exp. Mar. Biol. Ecol. 270, 203-214.

Satoh, .N., 1994. Developmental Biology of Ascidians. Cambridge University Press, 234 pp.

Stoner, D.S., 1989. Fragmentation: a mechanism for the stimulation of genet growth rates in an encrusting colonial ascidian. Bull. Mar. Sci. 45, 277-287.

Vervoort, H.C., Pawlik, J.R., Fenical, W., 1998. Chemical defense of the Caribbean ascidian Didemnum conchyliatum. Mar. Ecol. Prog. Ser. 164, 221-228.

Wasson, K., Zabinc, C. J., Bedinger, L., Diaz, M. C., Pearse, J. S., 2001. Biological invasions of estuaries without international shipping: the importance of intraregional transport. Biol. Conserv. 102, 143-153.

Whitlatch, R.B., Osman, R.W., Frese, A., Malatesta, R., Mitchell, P., Sedgwick, L., 1995. The ecology of two introduced marine ascidians and their effects on epifaunal organisms in Long Island Sound. In: Balcolm, N. (Ed.), Northeast conference on non-indigenous aquatic species. Connecticut Sea Grant College Program, Publication No. CT-SG-9504, pp. 29-48.

Worcester, S.E., 1994. Adult rafting versus larval swimming: dispersal and recruitment of a botryllid ascidian. Mar. Biol. 121, 309-317. 


\section{$\underline{\text { Figure Captions }}$}

Figure 1. Didemnum sp. A distribution on the east coast of the United States. Dotted line indicates approximate position of the $100 \mathrm{~m}$ isobath. The circled numbers indicate site locations as described in Table 1. Number 1 indicates the Damariscotta River, ME where Didemnum sp. A was first observed in the United States.

Figure 2. Didemnum sp. A distribution in southern New England, USA. The circled numbers indicate site locations as described in Table 1. Stellwagen Bank= Stellwagen Bank National Marine Sanctuary.

Figure 3. Didemnum sp. A distribution on the west coast of the United States. The circled numbers indicate site locations as described in Table 1. SF Bay = San Francisco Bay.

Figure 4. Morphology of Didemnum sp. A (A) Rope-like morphology common on docks, floats and vertical substrata. In this photograph flaccid lobes can be seen hanging from a colony growing on the underside of a sunken boat. (B) Mat-like morphology common on horizontal substrata. In this photograph a thick mat of Didemnum sp. A covers the entire bottom (viewed from above). 